\title{
De expert als goede procesbegeleider in het onderwijs*
}

\author{
J.B.M. Kuks
}

Een expert is een 'meester' die na het doorlopen van 'Lehrjahre' en 'Wanderjahre' actief ervaring heeft opgedaan. Zo'n expert is onmisbaar als procesbegeleider in het hoger onderwijs. Daar gaat het er immers niet meer om studenten te infiltreren met boekenwijsheid, maar om hen in de diepte te leren omgaan met onzekerheden, met tegenstrijdige kennis. Daar moet de student eigen wegen zoeken en een eigen stijl vinden.

Een volwassen expert kan in dit academische proces een excellente rol vervullen als begeleider door zich samen met de student te verbazen over wat er nu weer op diens weg gekomen is. Hij of zij kan dit doen door als kritische discussiepartner op te treden, door enthousiast te zijn over wat de student bij verrassing voor nieuws heeft ontdekt en door zich hardop af te vragen waarom die ontdekking niet eerder door hem- of haarzelf is gedaan. De expert kan nieuwe gedachten plaatsen in het kader van zijn of haar eigen, rijke ervaringen en er zo voor - of samen met - de student een ander licht op werpen. Hij of zij kan bij dit alles als rolmodel optreden.

Maar waar blijft daarbij de kennisoverdracht? Die vindt eveneens plaats op academische wijze en wel zo, dat duidelijk wordt hoe betrekkelijk sommige kennis is. Een orthodoxe meester die het allemaal wel zeker weet, die geen ongelijk wil krijgen, die zelf geen ontdekkingsreizen heeft gemaakt, maar alleen herhaalt wat hij van anderen hoorde of in de leerboeken las, is geen expert en is in het huidige academische onderwijs niet meer zo geschikt als procesbegeleider. Inmiddels moeten studenten zelf lezend en luisterend kennis kunnen absorberen. Het is zeker goed om zaken nog eens uit de mond van een ander te horen, maar van deze slechts bij herhaling getransporteerde feitenkennis blijft na de examens veelal weinig over. Een academisch student moet de informatie niet onvrijwillig frontaal in de schoot geworpen krijgen door de leermeester die het allemaal zo goed weet.

Vanuit een zelf doorleefde ervaring kan juist de expert een student kennis bijbrengen, waardoor de overdracht daarvan efficiënter zal verlopen. Hij of zij kan die kennis relativeren en zo de student bezielen in plaats van ontmoedigen; dit laatste gebeurt wanneer de nadruk ligt op een vermeende kennisachterstand. De student betrekt in de waardering van universitair docenten meestal het enthousiasme waarmee dezen doceren en de wijze waarop zij zich op het niveau van de student weten te bewegen. De goede docent is zo'n expert dat hij een deel laat zien van wat hij weet, maar ook van wat hij niet weet. Ook kan hij aangeven wat er hoe dan ook nog niet bekend is. Hij heeft zelf al veel bereikt en staat zo ver boven de materie dat hij niet hoeft te imponeren door grote feitenkennis. Liever brengt hij vanuit een academische houding een denkproces op gang en durft hij zich daarbij kwetsbaar op te stellen.

\footnotetext{
* Dit artikel is ook verschenen in het Nederlands Tijdschrift voor Geneeskunde (Ned Tijdschr Geneeskd. 2009;153:B302)
} 
Experts als docent kunnen met de student meeleven, mee zoeken en mee leren. De goede expert en procesbegeleider weet dat er in de Nederlandse taal slechts één woord bestaat voor het Duitse 'lehren' en 'lernen': leren.

De auteur:

Prof. dr. J.B.M. (Jan) Kuks is neuroloog, Universitair Medisch Centrum Groningen.

Correspondentieadres:

Prof.dr.J.B.M. Kuks; e-mail: j.b.m.kuks@neuro.umcg.nl

Belangenconflict: geen gemeld

Financiële ondersteuning: geen gemeld

\section{Correspondentie naar aanleiding van dit artikel}

\section{Ingezonden brief van prof. dr. Philip Kluin}

Het huidige onderwijs vormt artsen met verschillende competenties waar eerder te veel accent op kennisverwerving lag. Dat is een enorme verbetering. Toch vinden velen dat nu te weinig aandacht gegeven wordt aan kennisverwerving en dat oude onderwijsmethodes ten onrechte verlaten worden. Hieronder mijn lijstje argumenten tegen de docent als louter procesbegeleider:

1. Er is afgemeten aan de kwaliteit van de afgeleverde arts geen wetenschappelijk bewijs dat deze onderwijsvorm beter is.

2. Het is onwaarschijnlijk dat onderwijsvormen die millenialang goed functioneerden, nu niet voldoen.

N.B. Het brein van de student is neuroanatomisch waarschijnlijk ook niet veranderd.

3. Goed onderwijs maakt gebruik van de talenten van docenten. Het tutorsysteem met de vele groepjes maakt dat docenten noodgedwongen op niet-expertisegebieden worden ingezet. In onze afdeling onder andere zwangerschapscomplicaties, ARBO, triage bij letstel. Van 'doorleefde ervaring' is weinig sprake.

4. Door de complexe organisatie leidt procesgestuurd onderwijs tot grote, autonome onderwijsinstituten met een evenredig verminderde betrokkenheid van docenten.

5. Er is sinds de introductie van internet veel informatie beschikbaar. Ordening van de leerstof door experts is gewenst.

6. Veel studenten hebben behoefte aan diversiteit in onderwijsvormen.

Los van de strekking van het stuk staat er in het 'Pro' van collega Kuks: 'de docent moet de studenten in de diepte leren omgaan met onzekerheden, met tegenstrijdige kennis'. Is de schrijver niet erg zelfverzekerd?

Een extra reden om dit te schrijven is dat ook medische vervolgopleidingen nu sterk procesgestuurd dreigen te worden. Graag citeer ik dus minister Plasterk uit de NRC van 27 mei 2009:

'Ten eerste geen gepraat over stelsels. De kwaliteit van het onderwijs wordt vooral bepaald door wie er als docent voor de klas staat.' en: 'Je kunt het onderwijs plaatsen op een as tussen twee uitersten: het ontplooiingsmodel en het instructiemodel. In het eerste gaat de docent samen met de leerling op zoek naar wat de leerling kan en wil. In het instructiemodel weet de volwassene wat een kind moet leren en draagt de docent de kennis en vaardigheden over. De tendens is de laatste decennia te veel naar het eerste gegaan'. 
Graag dus niet te veel dogmatisme bij onderwijs en opleidingsvernieuwing.

Prof.dr. Philip Kluin, patholoog, Universitair Medisch Centrum Groningen, afd. Pathologie en Medische Biologie, Groningen

\section{Reactie van prof. dr J.B.M. Kuks op de in-} gezonden brief van prof. $d r$. P. Kluin

Ik ben collega Kluin dankbaar voor zijn opmerkingen. In reactie hierop het volgende.

\section{Ad 1)}

Er is geen gevalideerde maat om de kwaliteit van een arts te meten dus geen enkele onderwijsvorm kan men zo beoordelen.

\section{Ad 2a)}

Onderwijsvormen die millennia lang bestaan hebben zijn niet zo maar 'goed functionerend'. Ik ben niet tegen colleges. Het is een relatief goedkope onderwijsvorm, ze zijn relatief eenvoudig te maken en te geven. De docent leert er altijd veel van dus voor hem is het zeker een nuttige onderneming. Het merendeel van de studenten komt helaas vaak onvoorbereid en kan voorgekauwde kennis consumeren en simpel knikken (of knikkebollen); het is niet bewezen dat dit nuttig is.

2b)

Over eeuwenoude onderwijsvormen: toen het begrip academie (dat we immers zo graag gebruiken) opgang deed was kleinschalig onderwijs en de Socratische discussie juist dé manier om de leerling te vormen. Dat men in de middeleeuwen waar de klassieke eruditie en creativiteit als in een cocon gewikkeld lagen - hoorzittingen ging hanteren in het universitaire onderwijs is niet zo maar een aanbeveling voor de huidige praktijk. 2c)

Men moet hier niet de hersenen neuroanatomisch beschouwen. Het gaat om het cognitieve brein en dat verandert zeer snel. Denk aan verandering van mode en verandering van smaak in bijvoorbeeld kunstuitingen. De wijze waarop studenten het meest effectief benaderd kunnen worden verandert evenzo (Medical Education 2009; 43:398-405).

\section{Ad 3)}

In het algemeen moeten afgestudeerde artsen in de breedte van hun vak genuanceerd kunnen meepraten. In een goed onderwijssysteem is voorzien in centrale supervisie van een of meer experts waar de individuele docent voordeel uit kan putten.

Ad 4)

Evenals research doen is onderwijs verzorgen een professionele aangelegenheid waarvoor speciale expertise nodig is. Daarom zijn er onderwijsinstituten en onderzoeksscholen, niet zozeer vanwege kleinschalig onderwijs.

\section{Ad 5)}

Ordening van internetkennis door experts is gewenst maar men moet ook zelf een weg leren zoeken en niet levenslang klakkeloos 'opinion leaders' volgen.

\section{Ad 6)}

Hier volg ik collega Kluin onvoorwaardelijk.

Over mijn 'zelfverzekerdheid' wil ik opmerken dat men in een Pro-Contra rubriek een duidelijke stelling moet innemen. 